\title{
Evaluation of the position of lower incisors in the mandibular symphysis of individuals with Class II malocclusion and Pattern II profiles
}

Djalma Roque Woitchunas', Leopoldino Capelozza Filho² ${ }^{2}$ Franciele Orlando ${ }^{3}$, Fábio Eduardo Woitchunas ${ }^{4}$

Objectives: This study evaluated the position of mandibular incisors in the mandibular symphysis of individuals with Class II malocclusion and Pattern II profiles.

Methods: The sample consisted of 40 Caucasian patients (20 male and 20 female) with Class II malocclusion and Pattern II profile from 10 to 18 years of age (mean age of 12.84 years) who were selected from the records of the School of Dentistry of Universidade de Passo Fundo, Brazil. The linear cephalometric measurements used in this study were Ricketts' 1- AP, Interlandi's line I and Vigorito's 1-VT; and the angular measurement studied was the mandibular plane angle (IMPA).

Results: Mandibular incisors of individuals with Class II malocclusion and Pattern II profile tended to be buccally inclined and protruded.

Keywords: Diagnosis. Angle Class II malocclusion. Cranial circumference.

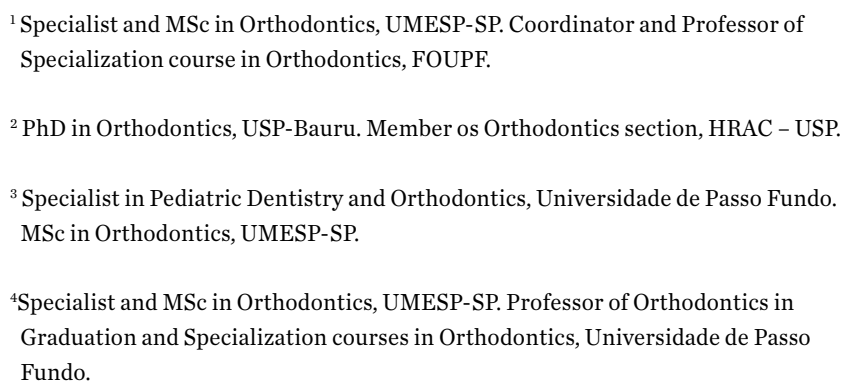

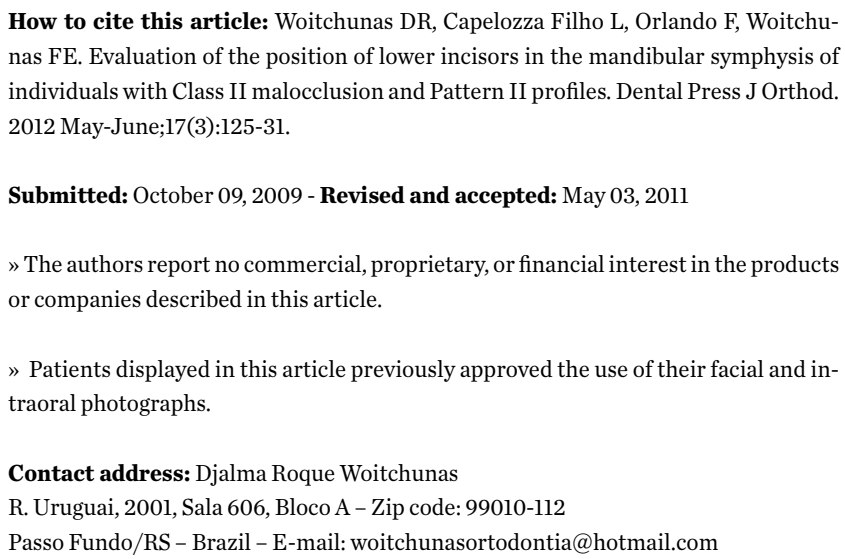

How to cite this article: Woitchunas DR, Capelozza Filho L, Orlando F, Woitchunas FE. Evaluation of the position of lower incisors in the mandibular symphysis of individuals with Class II malocclusion and Pattern II profiles. Dental Press J Orthod. 2012 May-June;17(3):125-31.

Submitted: October 09, 2009 - Revised and accepted: May 03, 2011

» The authors report no commercial, proprietary, or financial interest in the products or companies described in this article.

" Patients displayed in this article previously approved the use of their facial and intraoral photographs.

Contact address: Djalma Roque Woitchunas

R. Uruguai, 2001, Sala 606, Bloco A - Zip code: 99010-112

Passo Fundo/RS - Brazil - E-mail: woitchunasortodontia@hotmail.com 


\section{INTRODUCTION}

Morphological facial analysis is the main diagnostic resource to determine facial patterns, which may be classified as Pattern I, II or III, short face or long face. ${ }^{9,18}$ Individuals with a Pattern II face are characterized by the positive sagittal discrepancy between maxilla and mandible, ${ }^{9,18}$ and their facial characteristics are correlated with the two variables that determine classifications: the maxillary protrusion and mandibular deficiency. In most individuals Pattern II is defined by mandibular deficiency. ${ }^{6,9,14}$

An important characteristic of Pattern II is the position of mandibular incisors, which are a matter of concern due to their supposedly great importance in facial esthetics and in the stability of results after orthodontic treatments. ${ }^{3,5,8,15,19,23,26,27}$ So far, the parameters often used to evaluate the correct position of the mandibular incisors are cephalometric measurements, which associate these teeth with lines and planes that vary according to each author. These measurements have been defined for individuals with normal occlusion and harmonious faces, and, in most studies, no data for Brazilians have been included. 13,19,23,26

The stability of orthodontic treatment results should be improved if the orthodontist respects the morphology and functional characteristics of each individual. ${ }^{13}$ Individual variations, besides other factors, doesn't allow isolated fixed cephalometric goals due to the existing integration between facial and cranial structures. Therefore, individuals and their malocclusions can't all be treated by placing their mandibular incisors in the same position within basal bone. ${ }^{27}$

Dentoalveolar compensations should be mentioned as well, which are spontaneous changes in incisor position and inclination trying to achieve a good occlusion anteriorly and an acceptable anterior guidance in cases of sagittal skeletal disharmony. Therefore, compensation is the reverse of skeletal disharmony. In general, mandibular incisors play a more important role in compensations than maxillary incisors. ${ }^{4,8}$ For different anteroposterior relations of the apical bases, nature provides different compensatory inclinations of maxillary and mandibular incisors to ensure occlusion harmony. ${ }^{25}$

When in malocclusion, mandibular incisors are in a position of equilibrium and as teeth are moved, another position of equilibrium should be sought.
Therefore, anatomic, functional, cephalometric, periodontal and esthetic characteristics should be evaluated since they are the factors that limit incisor position. ${ }^{28}$ Buccal and lingual cortical bone are the anatomic limits for the movement of the incisors and, consequently, the limits of orthodontic treatment. ${ }^{12}$

Few papers have studied individual tooth inclinations in order to evaluate differences between normal occlusions in different ethnic groups and populations or to investigate torques and angles prescribed by different authors. ${ }^{10}$

This study evaluated the inclination of mandibular incisors of untreated individuals with Class II malocclusion and Pattern II profile in order to analyze their position and to discuss the possibilities of determining goals for their movement.

\section{MATERIAL AND METHODS}

The sample consisted of 40 Caucasian patients (20 male and 20 female) with a Class II malocclusion and a Pattern II profile with ages from 10 to 18 years (mean age 12.84 years) who were selected from the records of the School of Dentistry of Universidade de Passo Fundo, Brazil. The study was approved by the ethics committee of the same university (CEP 065/2006). The sample was selected according to profile and facial photographs and according to prior clinical examination. The facial photographs were taken using a Nikon Digital SLR camera at 6.1 effective mega pixels, 6.24 total mega pixels, Nikon DX format. Patients had not undergone orthodontic or orthopedic treatment and did not have any syndrome.

Lateral cephalometric radiographs were acquired at the Radiology Service of the School of Dentistry of Universidade de Passo Fundo using an Orthophos 5 cephalometer (OrthophosPlus, Siemens, Germany). Radiographies were scanned and analyzed using the Radiocef Studio 2 software according to the manufacturer's instructions. To obtain the cephalometric measures, cephalometric landmarks were defined by one single examiner.

The cephalometric measurements used in this study were:

» Linear: Ricketts' 1-AP, Interlandi's line I, Vigorito's 1-VT.

» Angular: Incisor mandibular plane angle (IMPA). 
Results were statistically analyzed. Means, medians and standard deviations were calculated, as well as minimum and maximum values of all variables under study. To check differences between genders, Student's t test for independent data was used and the level of significance was set at $5 \%$.

\section{RESULTS}

\section{Tooth relations to their apical bases}

Means, medians, standard deviations, minimum and maximum values of the measurements studied are shown in Table 1.

According to Table 1, the mean value of mandibular incisor in relation to Ricketts' AP line was $2.69 \mathrm{~mm}$, and the standard deviation was 3.28 . Most values in our sample were greater than the norm prescribed by the author.

The results of IMPA, whose mean was $95.7 \pm 5.83^{\circ}$, revealed that these teeth clearly tended to be in similar position or more proclined than
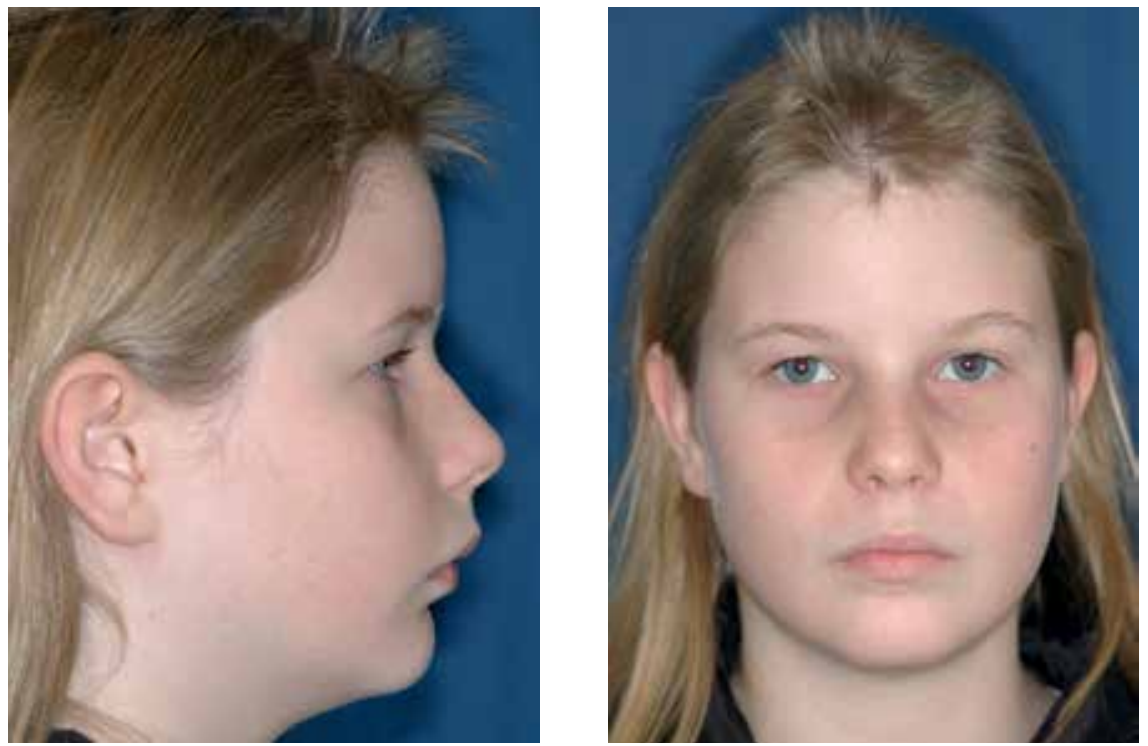

Figure 1 - Face and profile photographs of a Pattern II patient included in the study.
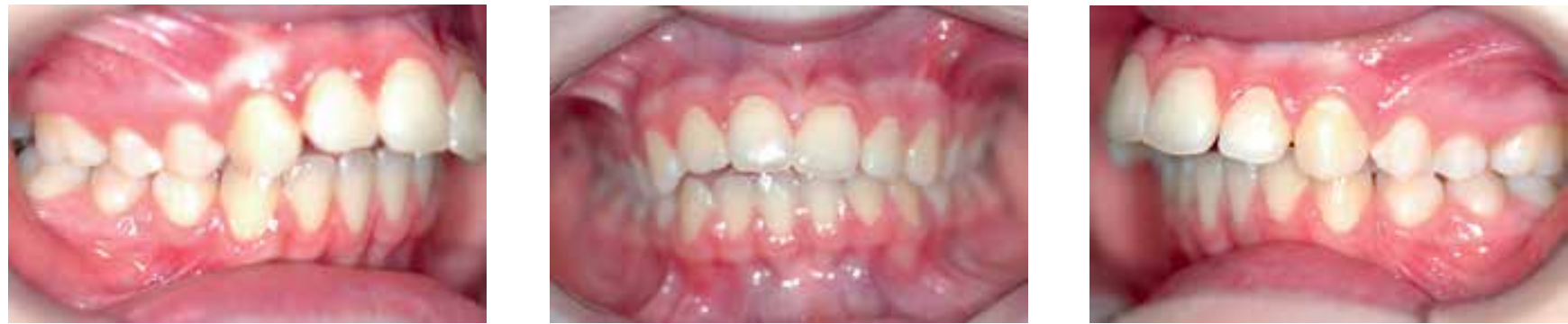

Figure 2 - Intraoral photographs of a Class II patient included in the study.
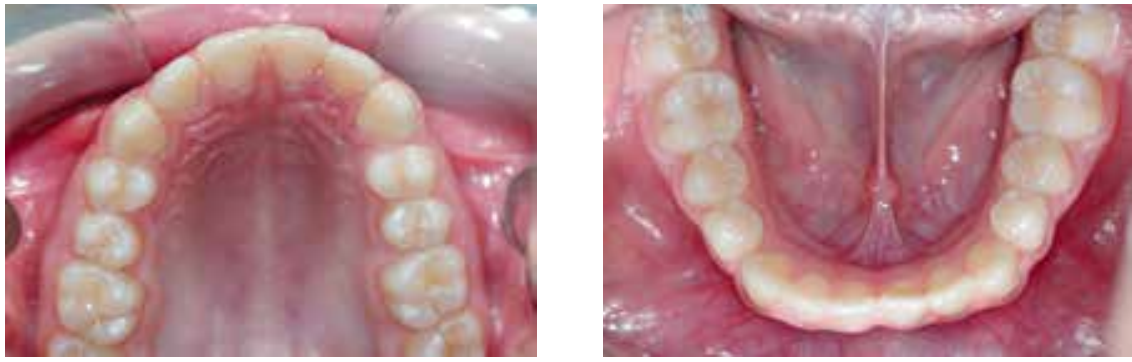

Figure 3 - Intraoral occlusal photographs of a Class II patient included in the study. 


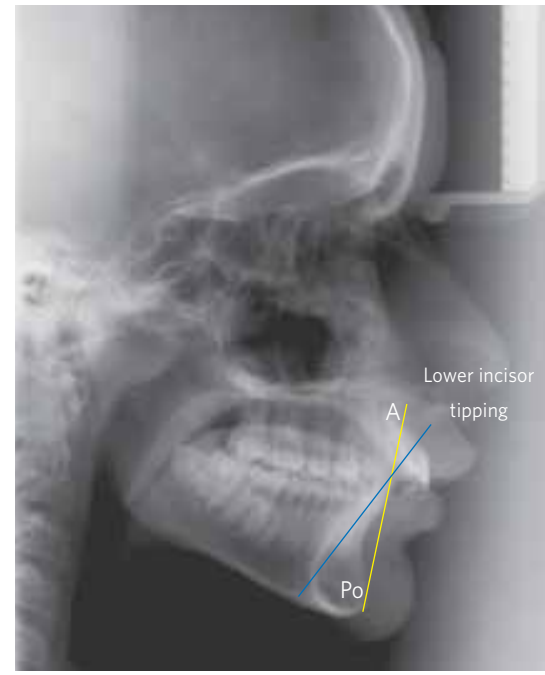

Figure 4 - Ricketts' 1-AP measurement.

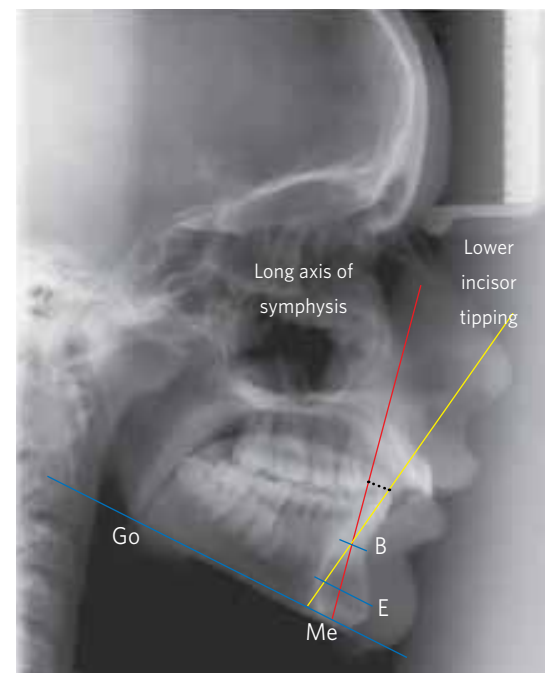

Figure 6 - Vigorito's 1-VT measurement.

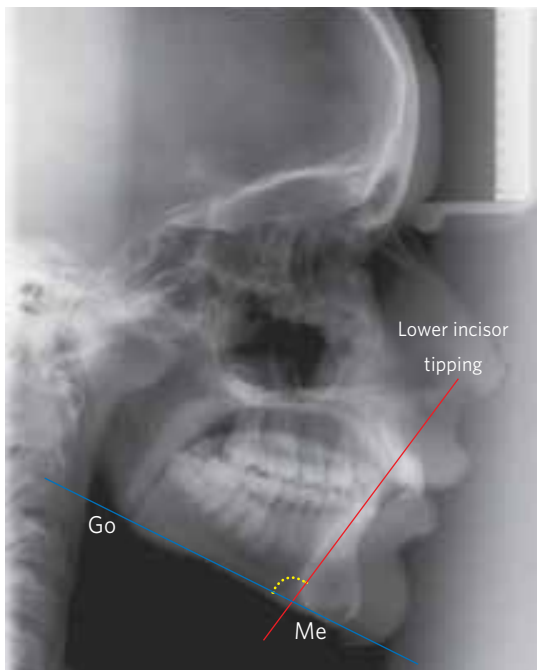

Figure 5 - IMPA measurement.

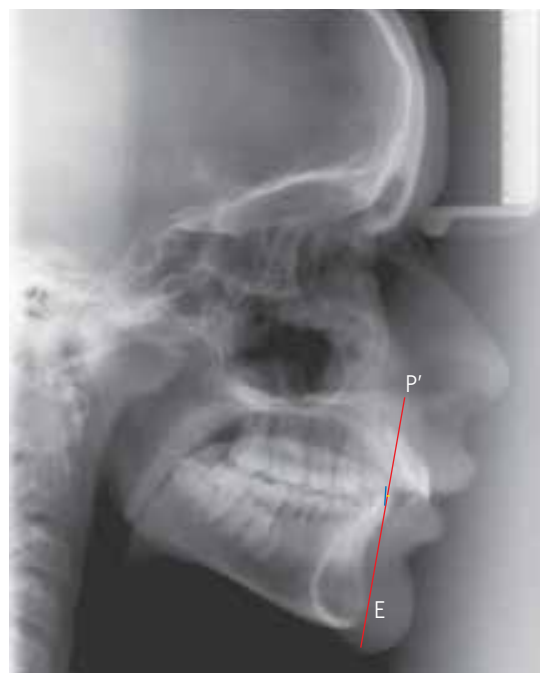

Figure 7 - Interlandi's line I measurement. the normal mean and most of the sample had values above the mean.

Interlandi's I line in the sample had a mean value of $-3.69 \pm 2.99 \mathrm{~mm}$, as seen in Table 1, indicating that incisors were more protruded than in individuals with normal occlusion. The other measure assessed, Vigorito's 1-VT, had a mean value of $7.40 \pm 2.74 \mathrm{~mm}$, which described the incisors' proclination.

Table 2 shows the comparison of the variables studied for both gender. According to results, there were no differences between genders.

\section{DISCUSSION}

Patients with a Pattern II profile are those that, through morphological facial analysis, have a positive sagittal relationship between the maxilla and the mandible, or a convex profile and other consequent changes. ${ }^{918}$ The individuals included in this study had a Pattern II profile and a Class II dental relationship.

According to our objectives, results were first compared with those obtained from a sample of white individuals with normal occlusion in the same area (Passo Fundo, Brazil). Second, comparisons 
Table 1 - Cephalometric measurements of the sample.

\begin{tabular}{cccccc} 
& Mean & Median & Standard Deviation & Minimum Value & Maximum Value \\
\hline Ricketts' 1-AP (mm) & 2.69 & 3.01 & 3.28 & -3.16 & 11.85 \\
IMPA (degrees) & 95.70 & 95.96 & 5.83 & 85.41 & 109.98 \\
Interlandi's I line (mm) & -3.69 & -4.20 & 2.99 & -10.05 & 1.52 \\
Vigorito's 1-VT (mm) & 7.40 & 6.95 & 2.74 & 0.2 & 16.25 \\
\hline
\end{tabular}

Table 2 - Comparison of cephalometric measurements between genders.

\begin{tabular}{ccccccc} 
& $\begin{array}{c}\text { Mean female } \\
\text { gender }\end{array}$ & Standard Deviation & $\begin{array}{c}\text { Mean male } \\
\text { gender }\end{array}$ & Standard Deviation & $\begin{array}{c}\text { Student's t } \\
\text { test }\end{array}$ & p \\
\hline Ricketts' 1-AP (mm) & 3.04 & 3.63 & 2.32 & 2.94 & 0.4911 & $>0.05^{\star}$ \\
IMPA (degrees) & 96.04 & 6.30 & 95.37 & 5.46 & 0.7208 & $>0.05^{\star}$ \\
Interlandi's I line (mm) & -3.75 & 3.24 & -3.63 & 2.81 & 0.9012 & $>0.05^{\star}$ \\
Vigorito's 1-VT (mm) & 7.14 & 2.69 & 7.65 & 2.83 & 0.5679 & $>0.05^{\star}$ \\
\hline
\end{tabular}

${ }^{\star}$ No statistical difference.

were made with findings of studies that evaluated patients with a Class II molar relationship and the norms established by their authors.

Table 2 shows the comparison of the cephalometric variables for both genders. There were no differences between genders, confirming findings by Vale and Martins, ${ }^{24}$ Aramaki et al, ${ }^{2}$ Woitchunas, ${ }^{28}$ Tukasan, ${ }^{22}$ and Reis et al. ${ }^{17}$ Therefore, gender was not included in the discussion.

The mean value of the relation of the mandibular incisor to Ricketts' AP line was $2.69 \pm 3.28 \mathrm{~mm}$; ranging from $-3.16 \mathrm{~mm}$ to $11.85 \mathrm{~mm}$. Ricketts studied normal occlusion and found a mean value of $0.5 \pm 2.5 \mathrm{~mm}$ and a forward inclination of the A-Pogonion plane in individuals with greater facial convexity, and a compensatory inclination of mandibular incisors in the same direction, with the opposite seen in straighter profiles. ${ }^{20}$ Woitchunas, in a study conducted in Passo Fundo, Brazil, selected a sample of Caucasian individuals with normal occlusion and found a similar mean of $2.41 \pm 1.68 \mathrm{~mm}$ compared to our findings, even though only patients with a Pattern II facial profile were enrolled. Therefore, in the samples with a Pattern II facial profile and with normal occlusion, in the same geographic area, incisors were protruded and different from those reported by Ricketts. ${ }^{19}$ Data found in our study showed that incisors were more protruded than in the sample studied by McNamara Jr., ${ }^{14}$ who found a mean value of $1.3 \pm 2.5 \mathrm{~mm}$ for patients with Class II, and by Vale and Martins, ${ }^{24}$ who evaluated Brazilians of Mediterranean descent with Class II, division I malocclusion and found a mean value of $1.70 \pm 3.21 \mathrm{~mm}$ for males and $1.48 \pm 2.85 \mathrm{~mm}$ for females.

The mean value of the relation of the mandibular incisors to Interlandi's I line was $-3.69 \pm 2.99 \mathrm{~mm}$; ranging from $-10.05 \mathrm{~mm}$ to $1.52 \mathrm{~mm}$. The value defining normal occlusion was $0 \mathrm{~mm} .{ }^{13}$ In 2002 , Interlandi referred to a study that included individuals with excellent occlusion and profiles with normal characteristics and found a mean I line value of $-1.28 \mathrm{~mm}$, ranging from $0.50 \mathrm{~mm}$ to $-2.50 \mathrm{~mm}$. Woitchunas ${ }^{27}$ found that I line had a mean value of $-2.96 \pm 2.96 \mathrm{~mm}$ in individuals with normal occlusion. The individuals with a Pattern II profile in our study had more protruded incisors in relation to Interlandi's I line than individuals with normal occlusion, but the similarity already demonstrated for 1-AP in the sample of individuals with normal occlusion in the same region was also found in our study.

The mean value of IMPA was $95.70 \pm 5.83^{\circ}$; ranging from 85.41 to $109.98^{\circ}$. According to Tweed, ${ }^{23}$ the value for individuals with normal occlusion is $90^{\circ}$. Aramaki et $\mathrm{al}^{2}$ evaluated Caucasian Brazilians with a Class II, division 1 malocclusion and found a mean value of $99.4 \pm 6.0^{\circ}$ before treatment with extractions, and $99.6 \pm 5.8^{\circ}$ for the group to be treated without extractions. Tukasan ${ }^{22}$ conducted a study on Brazilians with a Class II, division 1 malocclusion and found that IMPA was $94.38 \pm 6.90^{\circ}$. 
These values were similar to ours; and Aramaki et $\mathrm{al}^{2}$ found that incisors were more proclined. This sample was probably composed of individuals with maxillomandibular discrepancies more severe than those in our study.

The analysis of IMPA, a measure universally adopted to characterize AP position of mandibular incisors, revealed that in our sample these teeth clearly tended to have values that are equal to or greater than those considered to be the normal. The lower limit of the standard deviation was 89.97, a close value to the mean prescribed by Tweed. Therefore, a large number of the individuals in our sample had values above the mean. It is easy to understand these high IMPA values in this sample, and the reason why some individuals had the minimum value should be investigated. One possible explanation may be associated with maxillary protrusion in the Pattern II group, a limitation or a barrier to the compensatory proclination of mandibular incisors. ${ }^{9}$ This fact should be elucidated in future studies.

The mean value of 1 -VT was $7.40 \pm 2.74 \mathrm{~mm}$, ranging from $0.2 \mathrm{~mm}$ to $16.25 \mathrm{~mm}$. The value prescribed by Vigorito was $6 \mathrm{~mm},{ }^{27}$ found in a study of Caucasian individuals with normal occlusion. Woitchunas found a mean value of $6.17 \pm 1.36 \mathrm{~mm}$ in normal occlusions, ranging from 2.00 to $9.00 \mathrm{~mm}$. As for the minimum IMPA values, 1-VT values should be evaluated to improve the definition of the characteristics of the sample. These values show that incisors were more proclined in patients with Pattern II profile, which is fully compatible to the contemporary concepts that guide orthodontic practices.

A broader view of these results and comparisons suggests that individuals with Pattern II profiles tend to have a greater mandibular incisor proclination than those with a Class II malocclusion because the first always have a skeletal discrepancy in the maxillomandibular relationship, whereas the latter often have only a dental discrepancy that is responsible for the Class II relationship. Finally, $30 \%$ of all Class II do not correlate with a sagittal discrepancy between maxilla and mandible. ${ }^{18}$ Therefore, Class II malocclusions with Pattern II profiles demand dental compensation, often explicit by the proclination of incisors, which are not necessarily the case in Class II.

In contrast, the fact that two groups of individuals in the same geographic region, one with normal occlusion ${ }^{28}$ and the other with Class II malocclusions and Pattern II profiles have the same tendency to more proclination of incisors confirms the fact that compensation may be successful, resulting in normal occlusion. In the regular sample, there were some with a moderately increased maxillomandibular discrepancy who had enough and efficient compensation to determine normal relationships. Again, when compensation is successful, occlusion is normal. The offices of orthodontists are full of individuals treated by compensations who have normal occlusion.

The comparisons of the mandibular incisor position in this study sample and other norms described for the Brazilian population show that only I line had clinically significant differences. ${ }^{13}$ Although the mean value is higher, the difference is smaller when compared with the means of $1-\mathrm{VT} .{ }^{27}$ This may reflect characteristic of the measure itself rather than a sample characteristic. The method to define I line is very similar to that used for 1-AP, and both show similar and greater discrepancies between values found for the position of mandibular incisors among individuals with a Pattern II profile.

\section{CONCLUSIONS}

The results of this study suggest that mandibular incisors of individuals with Class II malocclusion and Pattern II facial profiles are proclined.

The comparisons of the mandibular incisor position in the Brazilian population show that IMPA values for most of the sample are equal to or greater than the value prescribed by Tweed. ${ }^{23}$ Ricketts' 1-AP measurements show that incisors are protruded in our sample in relation to the mean prescribed by Ricketts. ${ }^{20}$ For the Brazilian population, only I line has clinically significant differences. ${ }^{13}$

Therefore, it seems that whenever the treatment of Class II malocclusions in individuals with a Pattern II facial profile is compensatory, treatment goals should include a more proclination of mandibular incisors. 


\section{REFERENCES}

1. Andrews LF. The six keys to normal occlusion. Am J Orthod. 1972 Sep;62(3):296-309.

2. Aramaki RYI, Rino W, Takahashi T, Attizzani A, Maruo H, Miyahara M. Avaliação da inclinação do incisivo superior em indivíduos Classe II, divisão 1 de Angle: pré e pós-tratamento. Ortodontia. 2003 jan-abr;36(1):8-23.

3. Artun J, Garol JD, Little RM. Long-term stability of mandibular incisors following successful treatment of Class II, division 1, malocclusions. Angle Orthod. 1996;66(3):229-38.

4. Baca A. Mecanismos incisales de compensación de las disarmonías esqueléticas sagitales: resultados de un estudio sobre 500 pacientes maloclusivos. Rev Esp Ortod. 1992; 22(1): 36-52.

5. Berger $\mathrm{H}$. The lower incisors in theory and practice. Angle Orthod. 1959 29(3):133-48.

6. Bishara SE, Jakobsen JR, Vorhies B, Bayati P. Changes in dentofacial structures in untreated Class II division 1 and normal subjects: a longitudinal study. Angle Orthod. 1997;67(1):55-66.

7. Cabrera CAG, Freitas MR, Janson G, Henriques JFC. Estudo da correlação do posicionamento dos incisivos superiores e inferiores com a relação antero-posterior das bases ósseas. R Dental Press Ortodon Ortop Facial. 2005;10(6):59-74

8. Capelozza Filho L, Silva Filho OG, OzawaTO, Cavassan AO. Individualização de braquetes na técnica de Straight-Wire: revisão de conceitos e sugestão de indicações para uso. R Dental Press Ortodon Ortop Facial. 1999;4(4):87-106.

9. Capelozza Filho L. Diagnóstico em Ortodontia. Maringá (PR): Dental Press; 2004.

10. Capelozza Filho L, Fattori L, Maltagliati LA. Um novo método para avaliar as inclinações dentárias utilizando a tomografia computadorizada. R Dental Press Ortodon Ortop Facial. 2005;10(5):23-9.

11. Fattori L. Avaliação das inclinações dentárias obtidas pela técnica Straight-Wire - Prescrição Capelozza Classe II [Dissertação]. São Bernardo do Campo (SP) Faculdade de Odontologia da Universidade Metodista de São Paulo; 2006.

12. Handelman CS. The anterior alveolus: its importance in limiting orthodontics treatment and its influence on the occurrence of iatrogenic sequelae. Angle Orthod. 1996;66(2):95-109; discussion 109-10.

13. Interlandi S. Linha I na análise morfodiferencial para o diagnóstico ortodôntico. Rev Fac Odont S Paulo. 1971;9(2):289-310

14. McNamara JA Jr. Components of Class II malocclusion in children 8-10 years of age. Angle Orthod. 1981 Jul;51(3):177-202

15. Mucha JN. A estabilidade nas posições dos incisivos inferiores pós-tratamento ortodôntico. [tese de doutorado]. Rio de Janeiro (RJ): Universidade Federal do Rio de Janeiro; 1987
16. Pancherz H, Zieber K, Hoyer B. Cephalometric characteristics of class II division 1 and class II division 2 malocclusions: a comparative study in children. Angle Orthod. 1997;67(2):111-20.

17. Reis SAB, Capelozza Filho L, Claro CAA. Estudo comparativo de perfil facial de indivíduos Padrões I, II e III portadores de selamento labial passivo. Rev Dent Press Ortodon Ortop Facial. 2006 jul-ago;11(4):36-45.

18. Reis SAB, Abrão J, Capelozza Filho L, Claro CAA. Análise facial subjetiva. R Dental Press Ortodon Ortop Facial. 2006;11(5):159-72.

19. Ricketts RM. Cephalometric analysis and synthesis. Angle Orthod. 1961;31(3):141-56.

20. Rosenblum R. Class II malocclusion: mandibular or maxillary protrusion. Angle Orthod. 1995;65(1):49-62.

21. Tukasan PC. Craniofacial analysis of the Tweed Foundation in Angle Class II division 1 malocclusion. Braz Oral Res. 2005;19(1): 69-75.

22. Tweed $\mathrm{CH}$ The Frankfort-mandibular incisor Angle (FMIA) in orthodontic diagnosis, treatment and prognosis. Angle Orthod. 1954; 24(3):121-69.

23. Vale DMV, Martins DR. Avaliação cefalométrica das estruturas dento-esqueléticas em pacientes jovens portadores de Classe II, divisão 1, brasileiros, leucodermas e de origem mediterrânea. Ortodontia. 1987;20(1):5-17.

24. Vigorito JW, Mitri G. Avaliação de padrões cefalométricos em pacientes brasileiros leucodermas, portadores de "oclusão normal". Ortodontia. 1982;15(1):40-51.

25. Vigorito JW. Ortodontia clínica preventiva. 2ª ed. São Paulo (SP): Artes Médicas; 1986

26. Vigorito JW. Ortodontia clínica. Diagnóstico e terapêuticas. São Paulo (SP): Santa Madonna; 2004.

27. Woitchunas DR. Estudo comparativo cefalométrico radiográfico da aplicabilidade das análises cefalométricas de Interlandi, Vigorito e linha A-P de Ricketts, em adolescentes, com oclusão normal, do município de Passo Fundo, RS [Dissertação]. São Bernardo do Campo (SP): Instituto Metodista de Ensino Superior; 1994.

28. Woitchunas DR et al. Interpretação da correta posição do incisivo central inferior no diagnóstico e no planejamento ortodôntico. In: Siuza SC. Nova visão em ortodontia ortopedia funcional dos maxilares. São Paulo: Ed. Santos; 2003.

29. Zanelato ACT, Maltagliati LA, Scanavini MA, Mandetta S. Método para mensuração das angulações e inclinações das coroas dentárias utilizando modelos de gesso. R Dental Press Ortodon Ortop Facial. 2006;11(2):63-73. 